Article

\title{
Student Assessment of the Use of Kahoot in the Learning Process of Science and Mathematics
}

\author{
Marta Curto Prieto *, Lara Orcos Palma, Pedro Jesús Blázquez Tobías and \\ Francisco Javier Molina León \\ Facultad de Educación, Universidad Internacional de La Rioja, Logroño, 26006 La Rioja, Spain; \\ lara.orcos@unir.net (L.O.P.); pedrojesus.blazquez@unir.net (P.J.B.T.); \\ franciscojaviermolinaleon@gmail.com (F.J.M.L.) \\ * Correspondence: marta.curto@unir.net
}

Received: 18 January 2019; Accepted: 6 March 2019; Published: 12 March 2019

\begin{abstract}
One of the main objectives in education is to increase the motivation of the students to achieve meaningful learning. The use of technologies in classrooms which students are familiarized with such as the smartphone or the tablet, is a way to achieve this goal. On the other hand, it has been proven that the inclusion of scenarios supported by games and competition enhance the active participation of students. Therefore, in this work we present the results of a study based on of the application Kahoot with students of secondary education, in the subjects of mathematics, biology \& geology and physics \& chemistry, during the academic year 2017/2018. This tool allows students to answer to on-line questionnaires created by the teacher, through mobile devices, and check their results in a few seconds as well as those of their classmates. The results obtained on the assessment of the tool by students, in terms of the benefits in the learning process, have been very positive and help us to examine the potential of the use of on-line questionnaires in the classrooms.
\end{abstract}

Keywords: Kahoot; secondary education; mathematics; science; smartphone; tablet; Meaningful Learning; motivation

\section{Introduction}

The increasing use of technological resources in all areas of our daily lives has led to their implementation in the classrooms, in order to respond effectively to the demands of students [1-6]. As indicated by Gómez-Galán [7], this new reality in which we are immersed enables the inclusion of technologies, such as the tablet or the smartphone, to favor the development of digital competence. In this same line, the Horizon Report [8] indicates that the main technological trends in education for the next few years are Mobile Learning, Social Networks; Online Learning, Big Data, BYOD, Hybrid and Collaborative; Flipped Classroom, Cloud Computing, PLE, Gamification, Editing Robotics, Maker Spaces and Virtual Reality.

It is also important to highlight that the use of these types of tools greatly improves participation and motivation while increasing the meaningful learning in students, since they foster desire of students to learn due to the use of languages and technologies with which they are familiarized [9-16]. In this sense, Hernández \& Pérez [17] affirm that young people learn best when something is relevant to them, when there is a social connection with the concept to learn and when they really have a personal interest.

The results of the last Project for International Student Assessment (PISA) [18] show that the scores obtained by Spanish students in the fields of science and mathematics are below the average level of the Organization for Cooperation and Economic Development (ODCDE) and the European Union. The inclusion of these types of tools in the classroom can provide an improvement in the levels 
of motivation of students in science and mathematics subjects and, therefore, an improvement in their learning process.

The present study shows the resulting level of satisfaction towards the use of the application Kahoot, in terms of learning achievement, carried out by a sample of 68 students of second, third and fourth year of secondary education, between the ages of 12 and 16 years, in the subjects of mathematics, biology and geology and physics and chemistry, during the academic year $2017 / 2018$. This analysis is carried out from a previous study in which a methodological proposal to work with Kahoot Edpuzzle applications is designed [19].

The choice of this application in this study is determined by the few published experiences based on the use of these types of tools in subjects of science and mathematics in secondary education and the advantages of its use in the classroom, which generate an increase in the motivation of students, enhancing meaningful learning.

Some of these characteristics are: (a) that with this platform the teacher can generate a battery of questions that are sent to the students instantaneously, (b) that it is possible to answer the questions and obtain immediate feedback with the correct answer (c) that it is possible to use mobile devices, tablets and computers. On the other hand, Kahoot allows students to include images and videos, as well as to configure different variables, such as the time that the students have to answer the questions. In addition, students can see their position in the ranking of the scores, as the platform generates a classification once the different questions have been answered (Herreros, Pintor, López del Hierro, \& Chocker [20]).

This type of tool allows the creation of on-line questionnaires by the teacher that students answer with the use of the smartphones or tablets, with the possibility of having immediate feedback for each answer. This battery of questions can be launched at the beginning of the lesson, to check the previous knowledge of the students; in the middle of the class, to break the monotony and keep the attention of the students or at the end of the subject, to check the learning acquired. The use of these technologies allows the teacher to be informed of the degree of learning achieved by students and the statistics of the data almost immediately, thanks to the instant feedback of the results after the performance. It is also important to highlight that the use of the application allows the teacher to detect particular problems in the learning process with a certain topic and take the appropriate measures more effectively. They would, therefore, be a key piece in the initial, formative and final evaluation of the students.

Different studies on Kahoot agree that the use of these tools in the classroom not only improves the students' learning process but also their participation and the positive relationship among the class members. This is due to the fact that watching the correct answer between everyone in an instantaneous way, as well as assimilating the strategy as a game, allows comments to be shared among the students in a group and in a relaxed manner. It also facilitates the understanding and the participation of all the class, helping the development of social skills [6,11-16,21-24].

The main objective of this work is to analyze and compare the level of students' satisfaction, in terms of their opinions about how the use of Kahoot has help them in their learning process in science and mathematics. This is a preliminary study to develop an understanding of students' satisfaction in order to continue, later, with the assessment of the learning process.

\section{The Constructivist Approach and the Use of ICT in the Didactics of Science and Mathematics}

In order to choose a good methodological proposal, taking into account the constructivist approach, we consider it essential to keep in mind a sentence from Ignacio Estrada included in Hidalgo-Corredor [25] (p. 2): "If a child cannot learn throughout the way we teach him, perhaps we should teach him in the way he learns".

Fernández [26] regroups all the teaching methods in three major categories which are:

- Teaching methods based on the different ways of master exposure (master class, speech, conference, etc.). 
- Teaching methods oriented towards teamwork and debate (cooperative teaching, seminars, project-based learning, case studies, etc.).

- Teaching methods based on autonomous work or individual learning (learning contract, distance learning, programmed teaching, etc.).

De Miguel et al. [27] perform another type of classification of didactic methodologies, focusing on the competences, using the organizational modality of the teaching-learning process as the only criterion and indicating the purpose of:

- Theoretical Classes: to speak to students.

- Seminars-Workshops: to build students' knowledge throughout their interaction.

- Practical classes: to show students how they should act.

- External Practices: to complete the training of students in a professional context.

- Tutorials: to pay personal attention to students.

- Group work: to make students learn from each other.

- Autonomous work: to develop students's self-learning capacity.

The conjunction between theses methodologies and the ICT (Information and Communication Technologies) is the key to achieve a meaningful learning. As Area [28] comments, ICT are those resources and systems used to develop, store and disseminate digital information and are based on the use of computer technology. He also indicates that new technologies can be used in three different ways within the education system: "as an object of learning, as a means to learn and as a support to learning" [29] (p. 190).

Authors such as Ordóñez [30], Taber [31] \& Mattar [32] show that ICT relies on constructivist pedagogy to guarantee success in the teaching-learning process, indicating, in addition, what the process is and what its benefits are:

- Active and manipulable: since it involves students and encourages them to explore and interact, being aware of how this positively affects the outcome of their learning.

- Constructive and reflective: as it allows the student to acquire new knowledge and accommodate it to the previous one, performing a thinking process on their own learning.

- Intentional: as it is the student who determines the own goals and challenges, while the teacher supervises the process.

- Authentic, challenging and contextualized: since it prepares students to perform their tasks in real situations, preparing them for future challenges.

- Cooperative, collaborative and conversational: as it fosters social interaction among equals, being able to share ideas, clarify doubts and discuss problems.

Sánchez [33], however, indicates that the incorporation of ICT in the education system may entail some risks such as:

- It is possible that the students tend to be distracted due to the recreational time they are accustomed to make of.

- The volume of information can cause, for both students and teachers, the feeling of overflow when working with such a large amount of information.

- The lack of teachers' and students' training would reduce the potential of ICT in terms of its implementation in the classroom.

- Its implementation can lead to some situations in which students and teachers get used to making the least effort in the teaching-learning process, since the use of such a resource performs this task for them without needing any additional effort.

The incorporation of ICT in education implies, therefore, a renewal of teaching, both by teachers and the educational organization, so students can achieve a meaningful learning Fullan \& Langworthy [34]. 


\section{Smartphones and Online Questionnaires in the Classroom}

The technological evolution of mobile phones in recent years has led, as we can see in the Ditrendia report [35], a considerable increase in the acquisition of smartphones. In 2018, the number of mobile users in the world has increased to 5135 billion, which means that $68 \%$ of the world's population already has a mobile phone, evidencing that the trend of mobile use continues.

For Garrote [36], young people have not yet understood the true potential of technology. This makes it necessary to have an overall vision in the medium and long term, being the educator, the mediator and making the student the builder and designer of the content.

Brazuelo \& Gallego [37], Puigvert [38], Sevillano \& Vázquez-Cano [39], UNESCO [40] and Anshari, Almunawar, Shahrill, Kuncoro Wicaksono \& Huda [41] agree that a methodology, in which the smartphone is integrated in the classroom, requires an associated training system for its assessment, selection and contrast. For this reason, teachers have to use a methodology that adapts to the new instruments of management, access and treatment of information at any time and place [42].

Boyd [43] points out the importance of continuous and formative assessment in the teachinglearning process where the tests are part of the teaching routine, losing their extraordinary character.

Taking into account the importance that the continuous, summative and formative evaluation has in the education system, different imaginative alternatives have been sought, such as strategies based on the integration of objective tests or test-type exams, in which the results are quickly obtained after asking the students about some specific concepts [44].

Authors such as Pintor, Gargantilla, Herreros and López [11], indicate that the use of this type of questionnaires in which students answer certain questions posed by the teacher through an electronic device, enables teachers obtaining evidence of the student's learning process, while also encouraging their active collaboration and an increase of motivation.

\section{Kahoot}

In 2013, Alf Inge Wang developed a free access on-line program called "Kahoot" that allows us to carry out the same activities as can be done with Clickers (A system that consisted of a series of electronic controls used to answer and to know the results in real time of the questions asked by a speaker), but without the technical problems that were attributed to them. This application, instead of using remote controls and infrared receivers, only needs an internet connection, which can be obtained through any fixed or mobile device. In addition to the aforementioned advantage, Kahoot does not need previous software, knowledge or management, whereas the questions can be created in a very short time and in a simple way. Moreover, it allows the answers of all the students to be used since there is not a limited number of commands at a distance and, in addition, all interventions are recorded in an Excel file [11].

On the other hand, this tool allows us to elaborate multiple choice questions with the format and number required and to include images, videos and diagrams that make the design more attractive for students and, thus, increase motivation in the learning process [21].

Authors such as Zarzycka [12], Carrera \& Álvarez [13], Del Cerro [14], Fuertes et al. [15], Moya et al. [16] and Guimares [45], comment that Kahoot is an excellent didactic tool to carry out different activities in the classroom, contributing to the increase of students' participation and improving the existing relationship among different members of the group. In addition, authors such as Rodríguez-Fernández [46], indicate that Kahoot is presented as a game tool that allows the gamification and integration of the smartphone in the classroom.

It has been seen how the interaction between students and teachers can be improved through the use of mobile devices in the classroom, promoting an increase in students' motivation and in their participation and learning due to the competitiveness resulting from working through games [47]. 


\section{Methodology}

\subsection{Sample}

This study has been carried out with a sample of 68 students of second, third and fourth year of Compulsory Secondary Education (from 12 to 16 years old) for the evaluation of the use of the Kahoot tool in mathematics, biology and geology and physics and chemistry during the academic year 2017/2018 (33 students of science students and 35 students of mathematics). None of the students had used this tool before, so it is the first time they faced this type of methodology in the classroom.

\subsection{Investigation Design}

This study arises from a previous one in which the phases of a methodological approach based on the use of on line questionnaires in the classroom were developed [19].

This study has tried to go a step further with the aim of assessing the user experience after the use of the tool Kahoot. Pre-experimental research has been carried out to due to the fact that it involves a first approximation to the question of study which is the suitability of Kahoot, based on the analysis of results after the implementation of the methodological approach and it is also descriptive since the intention is to know the opinions of the system of study.

The questionnaires that have been used for the development of the subjects are composed of two types of questions: short answer, in which the students have had to answer a concise and specific question and another, multiple choice answer, in which students have had to choose the appropriate answer among the options proposed by the teacher.

\subsection{Information Collection Tools}

In order to obtain the information required for the students' satisfaction about the use of this tool in the teaching-learning process, we have worked with a questionnaire performed in Google Forms.

This questionnaire used is Driscoll Questionnaire designed in 2012, which has been used by authors such as Sacristán et al. [48], for development of their research in the field of Didactics of Mathematics. It has been chosen in this study due to the fact that it is based on the selection of the most representative and appropriate items to address the objective of this work.

The questionnaire consists of 12 items rated on a Likert scale ( 5 totally in agreement and 1 totally in disagreement). The items in the questionnaire are:

- My learning results have increased

- I had fun while learning

- My learning has been more autonomous

- I have improved my learning process

- I have worked more on my oral or written expression

- I have increased my creativity

- I have increased my motivation

- I think learning is more active and experiential

- I see more possibilities to show what I have learned

- I have more possibilities to work at my own pace

- I have had the facility to access the materials and contents

- I have been able to self-evaluate my learning process

\subsection{Procedure}

The methodology carried out in the classroom has been based on the following phases: 
1. Checking out of the previous knowledge of the students:

The previous knowledge of the students of the contents of each subject has been verified with an initial questionnaire carried out with the Kahoot tool.

To this end, short and multiple response questionnaires were prepared, in which the students had to answer specific questions related to the contents of previous courses, which will be necessary in order to build the new knowledge of this course.

This initial phase is considered necessary in the process since it allows the teacher to know the concepts that the students remember and, therefore, which areas they will have to emphasize the most.

2. Presentation of the content:

The new content to be discussed has been presented to the students by combining master classes with active and collaborative methodologies, in which, through the use of videos and other ICT tools, they could build their new knowledge autonomously as well as in groups.

Throughout the presentation of the contents, a contextualization of this information has been made so that the students could relate it to their day-to-day and closer environment, thus seeking to facilitate the comprehension of the new content.

The contents that have been worked on and treated with Kahoot tool have been: geometry in the subject of mathematics, the cell in biology and geology and the atom in physics and chemistry.

3. Verification of the new knowledge of students:

Once the contents have been presented by the teacher and worked on by the students, a content questionnaire has been answered through Kahoot so that each student, individually and with the help of the smartphones or tablets, answered the questions proposed by the teacher and whose statements were appearing in the PDI.

4. Thinking process:

Once the questionnaire has been completed, the application will return the individual results of each student in the class, as well as the statistics of the questions, which enables us to immediately detect possible gaps in the knowledge of the content. To clarify the contents that have not been properly learnt by the students, a thinking process based on the analysis of the results achieved is necessary, which aims to be revealing for the students because they will be able to clarify doubts.

When doing this type of reflections in the classroom, the students go through two different stages, the first, a personal reflection in which they can analyze and reflect on their chosen results and responses and, the second, a group reflection in which they can discuss and reflect on their answer choices with the rest of the classmates and with the teacher. In this way, it is expected that students both individually and in groups, can participate in the construction of their new knowledge.

5. Answering the user experience evaluation questionnaire after using the tool:

Once the students have used the tool, their user experience is evaluated in terms of their opinions for the contribution for the learning process.

This final phase is of vital importance, since through the assessment questionnaire of the use of Kahoot, students leave evidence of their opinion and feelings after having used this tool in two different periods, the first, before addressing the new contents to value the prior knowledge and the second, once the new contents have been exposed and worked on, to demonstrate and check their understanding.

In this way, through the assessment questionnaire of Kahoot, it is expected to be able to analyze different criteria such as, "I have increased my motivation", or as "I have fun learning", which can show the opinion and satisfaction of the students with the use of this tool. 


\subsection{Data Analysis}

The analysis of the data obtained after the assessment of the items of the questionnaire has been quantitative based on a descriptive analysis. The average values of each item and the percentages of answers of each level (1 to 5), have been obtained distinguishing between Mathematics and Science subjects.

\section{Results and Discussion}

In global terms, the average level of the items of the questionnaire is 3.6 with a mean standard deviation of 0.098 that implies that, in general, students positively value the use of the tool, being the dispersion between the means of the values of each item very small. In Figure 1 we include the average values of the items of the questionnaire assessed by students of mathematics and Figure 2 by students of science.

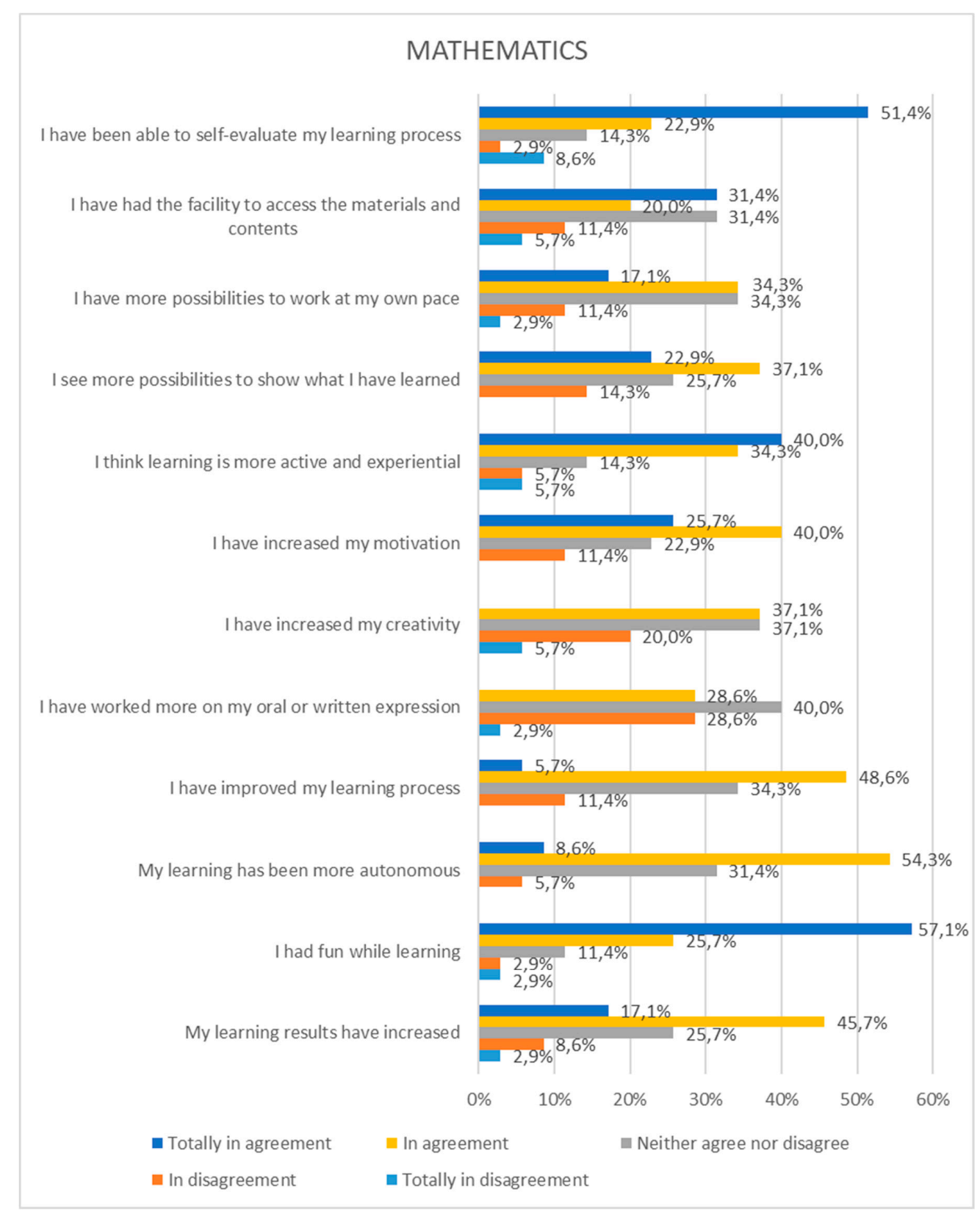

Figure 1. Evaluation percentages of the levels per questionnaire item among Mathematics students. 


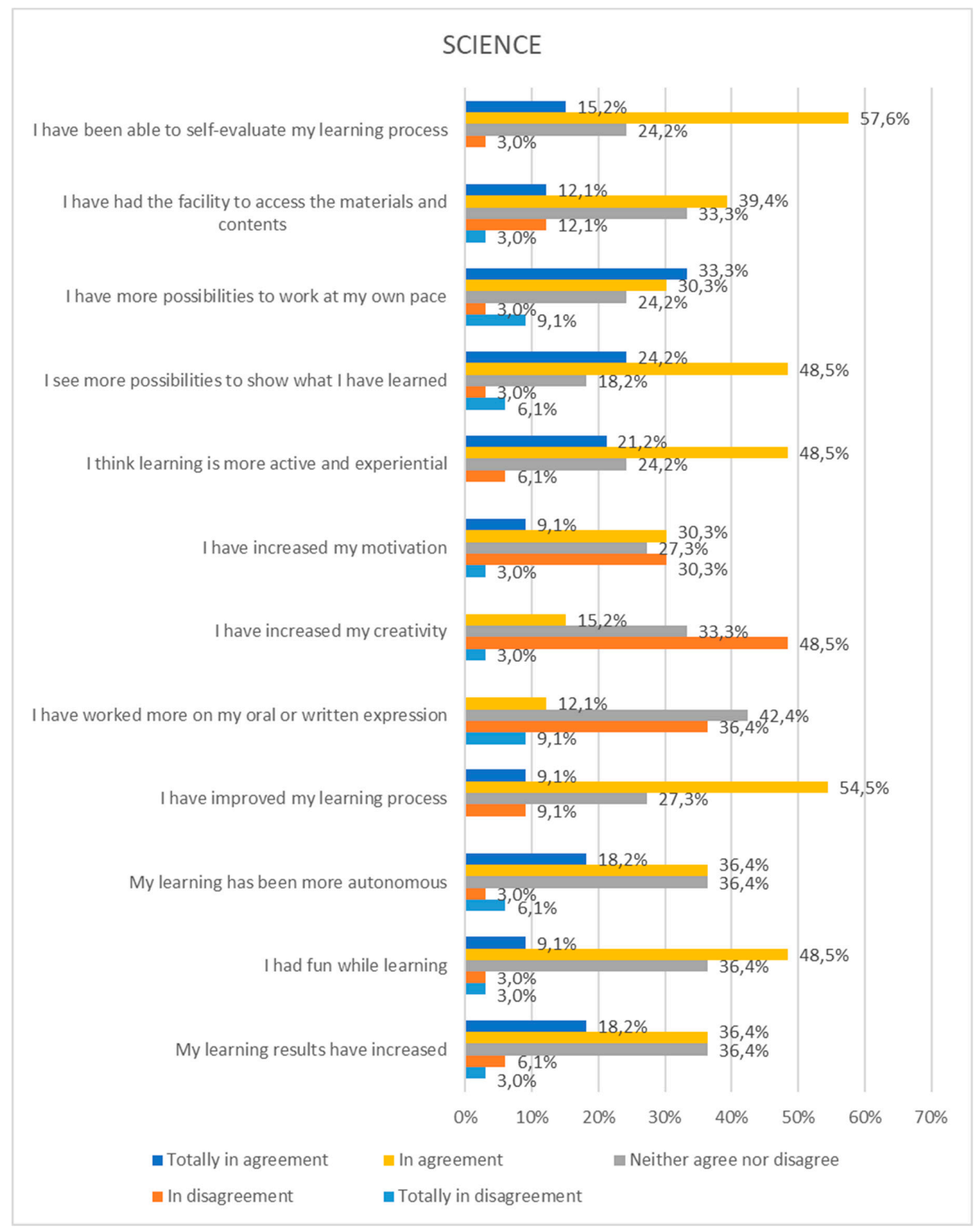

Figure 2. Evaluation percentages of the levels per questionnaire item among science students.

As it can be seen in Figure 1, the items "I have fun while learning," "I have been able to self-evaluate my learning process" and "I think learning is more active and experiential" showed a higher percentage of students choosing level 5 (totally in agreement). The rest of the items have been mostly valued with level 4 (in agreement) with the exception of the items "I have worked more on my oral and written expression", "my creativity has increased" and "I had facility to access the materials" in which student responses showed an average of level 3.

As can be seen in Figure 2, science students have not valued the tool as much as the ones who have used it in mathematics. The only item that has obtained a higher percentage for level 5 was "I have more possibilities to work at my own pace". The highest percentages of level 4 were obtained in the items "I have been able to self-evaluate my learning process", "I have fun while learning", "I have improved my learning process" "I have been able to show what I have learned" and "I believe that learning is more active and experiential". On the other hand, students comment that they do not agree 
about having improved their oral or written expression and they do not consider that their creativity has increased.

In Figure 3 we include the comparison between the average values per item in both subjects.

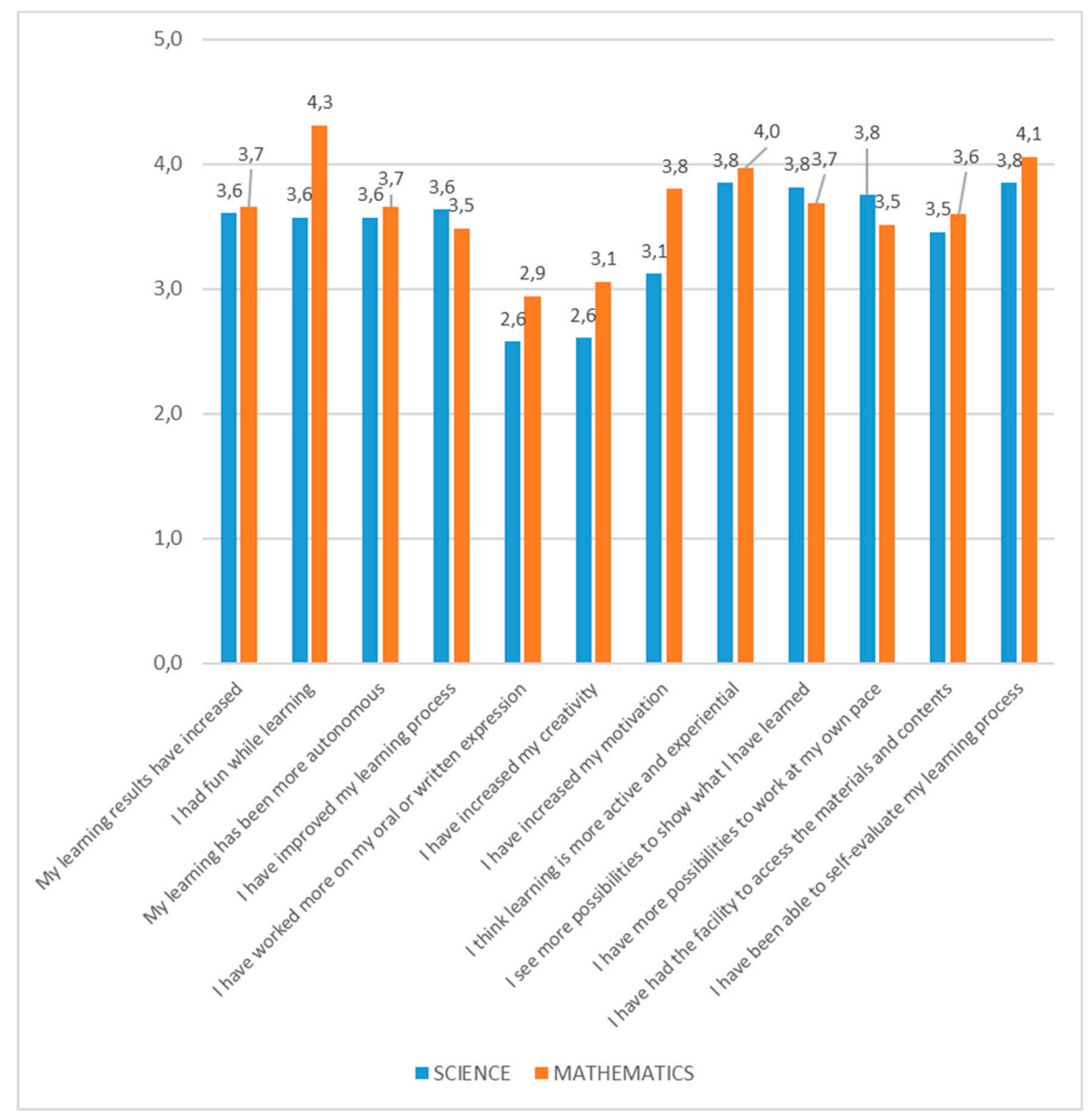

Figure 3. Comparison between the average values in Mathematics and Science.

As shown in Figure 3, the average values obtained in each item are mostly similar for each subject. Now we describe the results distinguishing between the items in which the level of satisfaction has been high in both subjects, the ones in which it has been different and the ones in which it has been low in both subjects.

- The items "My learning results have increased" and "My learning has been more autonomous" have very similar values for the subjects of both science and for mathematics, 3.6 and 3.7 respectively, which are also the same as the average global value (3.6). These values indicate that students of both subjects consider that the tool has helped them to increase their learning results, which have also been more autonomous. Something similar happens with the items "I think learning is more active and experimental", with values of 3.8 and 4, for Science and Mathematics respectively, "I see more possibilities to show what I have learned", with 3.7 and 3.8 respectively and "I have been able to self-evaluate my learning process", with 3.8 and 4.1. These results lead us to conclude that students appreciate the use of Kahoot in terms of the benefits for the learning process when they have taken the main role, while they have developed a reflective metacognition and have been able to self-assess. 
- Regarding the item "I had fun while learning", it can be seen that the students of mathematics have enjoyed using Kahoot more than science students since the average values are 4.3 and 3.6 respectively. The results obtained in the item "I have increased motivation", show that there also exists a difference between the students of science (3.1) and mathematics (3.8) in this area. However, the item "I have more possibilities to work at my own pace" has been better assessed by students of science that by the students of mathematics ( 3.8 and 3.5 respectively) These facts may be a consequence of the teaching of mathematics, which tends to use more traditionalist and less innovative methodologies that can have a negative impact on the student's motivation and the possibility to learn at their own pace, which means that the use of this type of tool can influence positively on it.

- According to the results of the item "I have worked more on my oral or written expression" (2.6 and 2.9 in science and mathematics respectively), we can say that in general students believe they have not used these skills much, although the score in Mathematics is higher. We believe this fact can be due to the idiosyncrasy of the mathematical concepts and definitions which are more abstract, so in some situations they did not spend as much time on their explanation as in their application. Something similar happens with the item "My creativity has increased", in which the average value for science is 2.6 and for mathematics is 3.1. Although in general terms, students consider that they have not used creativity much, the ones of Mathematics value this item better than the ones of Science. We believe this conclusion is an obvious one, since students did not have to create the questionnaire.

\section{Conclusions}

It is important to clarify that the main objective of this work was to analyze and compare the level of students' satisfaction, in terms of their opinions about how the use of Kahoot has helped them in their learning process, when used as a way to review the contents related to mathematics and science subjects. For this reason, we cannot make real conclusions about what the use of Kahoot has meant in the learning process of the students of the sample, due to the fact that we have just valued their perceptions.

To achieve this, a previous bibliographical review allowed us to establish the theoretical foundations on which the to base the use of ICT in the constructivist paradigm. This review allows us to corroborate the statements in references [30-32] about the direct relationship between the use of ICT and active and meaningful learning.

The results obtained, after the assessment, have been very positive. Globally, the students consider that they have been able to self-evaluate their learning process, which has been more active and experiential and they have had the possibility to better show what they have learnt, which is very interesting from the point of view of the metacognitive process.

There is a difference in the evaluation of the items when they are analyzed separately according to whether the tool has been used in science or mathematics classes. Math students had more fun and have felt more motivated with the tool than science students. This difference can be due to the idiosyncrasy of mathematical concepts, which are difficult to put in real contexts, which leads to students getting bored in class, so when a participatory classroom methodology is applied, the students value it more highly in terms of fun and motivation. Moreover, mathematic concepts do not require such rote learning as scientific concepts, so students could feel more motivated when answering the content questionnaire after the experience, as they could get better results.

There are two items that have not been developed from the point of view of students, which are the increase of creativity and the development of the capacity of oral and written expression. For this reason, at the prospective level, we propose some modifications of the use of the tool, for example to enable students to prepare the questions to be answered by the rest of the classmates, as a review.

The online questionnaires based on test questions, whose response is obtained almost instantaneously, allow a formative evaluation by the teacher, who can have information about 
the knowledge obtained by the student. In turn, and as indicated by Rodríguez-Fernández [46], the game-like format on which questionnaires of this type are based, such as Kahoot, increases student motivation, thus generating an improvement in the process of teaching and learning.

As a conclusion we can say that the integration of mobile devices in the classroom, such as the smartphone, used by students on a daily basis, favors the teaching-learning process. In this way, an atmosphere is created in the classroom based on motivation and improvement in the acquisition of new contents, which always includes an adequate control system for the teacher and the characteristics of the group-class [49].

Finally, at a prospective level, an experimental study is proposed to be performed to be able to compare the academic results of a control group and an experimental group that uses the Kahoot tool and, in this way, to be able to assess what it means for their learning process. In addition, a comparative study between courses can be interesting in order to make a comparison, taking into account more cognitive aspects, as well as to apply the tool in more subjects and courses. On the other hand, it is proposed to make a comparison between the user experience of Kahoot and other tools such as Socrative or Edpuzzle.

Author Contributions: All authors have contributed equally in writing this article. All authors read and approved the final manuscript.

Funding: This work was supported in part by Universidad Internacional de La Rioja (UNIR).

Conflicts of Interest: The authors declare no conflict of interest.

\section{References}

1. Codesal, M.B. Xogando aos oficios na Educación Primaria. Un proxecto con Minecraft. Revista Galega de Educación 2017, 68, 22-25.

2. Haydn, T.; Ribbens, K. Social Media, New Technologies and History Education. In Palgrave Handbook of Research in Historical Culture and Education; Carretero, M., Berger, S., Grever, M., Eds.; Palgrave Macmillan: London, UK, 2017.

3. Briz-Poncea, L.; Pereirab, A.; Carvalhoc, L.; Juanes-Méndeza, J.A.; Francisco José García-Peñalvo, F.J. Learning with mobile technologies—Students' behavior. Comput. Hum. Behav. 2017, 72, 612-620. [CrossRef]

4. Pérez, S.D. El uso de los dispositivos móviles en clase de Historia: Experiencia de uso de Kahoot como herramienta evaluadora. Didáctica Innovación y Multimedia 2017, 35, 1-11.

5. San Martín, A.; Peirats, J. Repasando la labor pedagógica en la escuela. Del libro de texto a los textos sin libros. TELOS 2017, 106, 39-46.

6. Marín, D.; Vidal Esteve, M.I.; Peirats Chacón, J.; López Marí, M. Gamificación en la evaluación del aprendizaje: Valoración del uso de Kahoot! In Innovate strategies for Higher Education in Spain; REDINE, Ed.; Adaya Press: Eindhoven, The Netherlands, 2018; pp. 8-17.

7. Gómez-Galán, J. Nuevos estilos de enseñanza en la era de la convergencia tecno-mediática: Hacia una educación holística e integral. Int. J. Educ. Res. Innov. (IJERI) 2017, 8, 60-78.

8. Horizon, I. Higher Education Edition; The New Media Consortium: Austin, TX, USA, 2017.

9. Green, K.R.; Pinder-Grover, T.; Millunchick, J.M. Impact of screencast technology: Connecting the perception of usefulness and the reality of performance. J. Eng. Educ. 2012, 101, 717. [CrossRef]

10. Lloyd, S.A.; Robertson, C.L. Screencast tutorials enhance student learning of statistics. Teach. Psychol. 2012, 39, 67-71. [CrossRef]

11. Pintor, E.; Gargantilla, P.; Herreros, B.; López, M. El Aprendizaje Basado en Juegos: Experiencias Docentes en la Aplicación de la Plataforma Virtual "Kahoot". XI Jornadas Internacionales de Innovación Universitaria. Educar Para Transformer 2014. Available online: http:/ / abacus.universidadeuropea.es/bitstream/handle/ 11268/3603/x_jiiu_2014_322.pdf?sequence=2\&isAllowed=y (accessed on 20 November 2017).

12. Zarzycka, E. Kahoot it or not? Can games be motivating in learning grammar? Teach. Engl. Technol. 2014, 16, 17-36. Available online: https:/ / www.ceeol.com/search/article-detail?id=420768 (accessed on 21 November 2017). 
13. Carrera, D.A.; Álvarez, L.A. Sistemas de Respuesta en Aula de Libre Distribución para uso con Dispositivos Móviles. Actas V Encuentro Conferencias Chilenas en Tecnologías del Aprendizaje. Arica 2015. Available online: http:/ / eudev.uta.cl/cclt2015/pdf/Carrera_Escobar.pdf (accessed on 21 November 2017).

14. Del Cerro, G. Aprender Jugando, Resolviendo: Diseñando Experiencias Positivas de Aprendizaje. XII Jornadas Internacionales de Innovación Universitaria Educar para Transformar: Aprendizaje Experiencial 2015. Available online: http:/ / abacus.universidadeuropea.es/bitstream/handle/11268/4334/jiiu_2015_ 28.pdf? sequence $=2 \&$ isAllowed $=y$ (accessed on 21 November 2017).

15. Fuertes, A.; García, M.; Castaño, M.A.; López, E.; Zacares, M.; Cobos, M.; Ferris, R.; Grimaldo, F. Uso de Herramientas de Respuesta de Audiencia en la Docencia Presencial Universitaria. Un Primer Contacto. Actas de las XXII Jenui. Almería 2016. Available online: https:/ / www.uv.es/grimo/publications/jenui2016.pdf (accessed on 21 November 2017).

16. Moya, M.M.; Carrasco, M.; Jiménez, M.A.; Ramón, A.; Soler, C.; Vaello, M.T. El Aprendizaje Basado en Juegos: Experiencias Docentes en la Aplicación de la Plataforma Virtual “Kahoot". Actas XIV Jornadas de Redes de Investigación en Docencia Universitaria. Alicante 2016. Available online: https:/ / web.ua.es/es/ ice/jornadas-redes-2016/ (accessed on 22 January 2017).

17. Hernández, F.A.L.; Pérez, M.M.S. Factores que inciden en la aceptación de los dispositivos móviles para el aprendizaje en educación superior. Estudios Sobre Educación 2016, 30, 175-195.

18. Organización para la Cooperación y el Desarrollo Económicos y Ministerio de Educación, Cultura y Deporte, Secretaria General Técnica. Pisa 2015. Programa para la Evaluación Internacional de los Alumnos. Informe Español; Organización para la Cooperación y el Desarrollo Económicos y Ministerio de Educación, Cultura y Deporte, Secretaria General Técnica: Madrid, Spain, 2015.

19. Orcos, L.; Blázquez, P.J.; Curto, M.; Molina, F.J.; Magreñán, Á.A. Use of Kahoot and EdPuzzle by Smartphone in the Classroom: The Design of a Methodological Proposal. In LTEC 2018: Learning Technology for Education Challenges; Uden, L., Liberona, D., Ristvej, J., Eds.; Communications in Computer and Information Science; Springer: Cham, Switzerland, 2018; Volume 870.

20. Herreros Ruiz Valdepeñas, B.; Pintor Holguín, E.; López del Hierro, M.; Gargantilla Madera, P. Kahoot en Docencia: Una alternativa Practica a los Clickers; Universidad Europea: Madrid, Spain, 2014.

21. Jaber, J.R.; Arencibia Espinosa, A.; Carrascosa Iruzubieta, C.; Ramírez, A.S.; Rodriguez-Ponce, E.; Melián, C.; Farray, D. Empleo de Kahoot! como Herramienta de Gamificación en la Docencia Universitaria. III Jornadas Iberoamericanas de Innovación Educativa en al Ámbito de las TIC 2016. Available online: http: / / acceda. ulpgc.es/handle/10553/20472 (accessed on 21 November 2017).

22. Martínez, G. Tecnologías y nuevas tendencias en educación: Aprender jugando. El caso de Kahoot. Revista de Ciencias Humanas y Sociale 2017, 83, 252-277.

23. Ramírez Covarrubias, A.C.; Arciniega Luna, A.; Iriarte Solís, A.; Arriaga Nabor, M.O. Aplicaciones educativas para la enseñanza: Caso de estudio Kahoot! Educateconciencia 2017, 16, 140-149.

24. Bryant, S.G.; Correll, J.M.; Clarke, B.M. Fun with Pharmacology: Winning Students over with Kahoot! Game-Based Learning. J. Nurs. Educ. 2018, 57, 320. [CrossRef] [PubMed]

25. Hidalgo-Corredor, R. El uso de las TIC en la Educación Personalizada: Potencialidades en el Proceso de Enseñanza-Aprendizaje; Universidad Internacional de La Rioja: Madrid, Spain, 2014.

26. Fernández, A. Nuevas Metodologías Docentes; Instituto de Ciencias de la Educación, Universidad Politécnica de Valencia: València, Spain, 2008.

27. De Miguel Díaz, M.; Alfaro Rocher, I.; Apodaca Urquijo, P.; Arias Blanco, J.; García Jiménez, E.; Lobato Fraile, C. Metodologías de Enseñanza y Aprendizaje Para el Desarrollo de Competencias. Orientaciones para el Profesorado Universitario ante el Espacio Europeo de Educación Superior; Alianza Editorial: Madrid, Spain, 2006.

28. Area, M. Las Nuevas Tecnologías de la Información y Comunicación en la Educación. Biblioteca Virtual del Grupo de Tecnología Educativa de la Universidad de Sevilla 2002. Available online: http:/ / tecnologiaedu. us.es/nweb/htm/bibliovir-docs.asp (accessed on 27 November 2018).

29. Area, M. Un análisis de las actividades didácticas con TIC en las aulas de educación secundaria. Medios y Educación 2010, 38, 187-199.

30. Ordóñez, J.E. Estudio Sobre el uso de las Tecnologías de Información y Comunicación (TICs) en el Área de Lengua y Literatura Dentro de los Establecimientos de Educación Básica. Tesis Doctoral, Universidad Tecnológica de Israel, 2012. Available online: http: / /repositorio.uisrael.edu.ec/handle/47000/618 (accessed on 21 November 2017). 
31. Taber, K.S. The Role of New Educational Technology in Teaching and Learning: A Constructivist Perspective on Digital Learning. In Handbook on Digital Learning for K-12 Schools; Marcus-Quinn, A., Hourigan, T., Eds.; Springer: Cham, Switzerland, 2017; pp. 397-412.

32. Mattar, J. Constructivism and connectivism in education technology: Active, situated, authentic, experiential, and anchored learning. RIED Revista Iberoamericana de Educación a Distancia 2018, 21, 201-217. [CrossRef]

33. Sánchez, M.J.P. Ventajas e inconvenientes de las tic en la docencia. Revista Digital Innovación y Experiencias Educativas 2007, 25, 1-8. Available online: http:/ / www.csi-csif.es/andalucia/modules/mod_ense/revista/ pdf/Numero_25/MARIA_JOSE_PALOMAR_SANCHEZ01.pdf (accessed on 9 January 2017).

34. Fullan, M.; Langworthy, M. Towards a New End: New Pedagogies for Deep Learning; Collaborative Impact: Seattle, WA, USA, 2013.

35. Rivero, F. Informe ditrendia 2016: Mobile en España y en el Mundo. Available online: http:/ / www.ditrendia. es/wpcontent/uploads/2016/07/Ditrendia-Informe-Mobile-en-Espa na-y-en-el-Mundo-2016-1.pdf (accessed on 7 March 2019).

36. Garrote, G. Uso y Abuso de Tecnologías en Adolescentes y su Relación con Algunas Variables de Personalidad, Estilos de Crianza, Consumo de Alcohol y Autopercepción como Estudiante. Tesis Doctoral, Universidad de Burgos, 2013. Available online: http:/ /hdl.handle.net/10259/219 (accessed on 21 November 2017).

37. Brazuelo, F.; Gallego, D. Mobile Learning. Los Dispositivos Móviles Como Recurso Educativo; MAD Eduforma: Sevilla, Spain, 2011.

38. Puigvert, L. Teorías y Sociedades Dialógicas. Nuevas Transferencias Ciencia Sociedad en la era del Conocimiento; Programa Nacional de Promoción General del Conocimiento; Ministerio de Ciencia y Tecnología: Madrid, Spain, 2006.

39. Sevillano, M.L.; Vázquez-Cano, E. Modelos de Investigación en Contextos Ubicuos y Móviles en Educación Superior; McGraw-Hill: Madrid, Spain, 2015.

40. UNESCO: Organización de las Naciones Unidas Para la Educación, la Ciencia y la Cultura. Directrices Para las Políticas de Aprendizaje Móvil 2013. Available online: http:/ / unesdoc.unesco.org/images/0021/ 002196/219662S.pdf (accessed on 21 November 2017).

41. Anshari, M.; Almunawar, M.N.; Shahrill, M.; Kuncoro Wicaksono, D.; Huda, M. Smartphones usage in the classrooms: Learning aid or interference? Educ. Inf. Technol. 2017, 22, 3063-3079. [CrossRef]

42. Vázquez-Cano, E. El reto de la formación docente para el uso de dispositivos digitales móviles en la educación superior. Perspect. Educ. 2015, 54, 149-162.

43. Boyd, H.; y Cowan, J. A Case for Self assessment based on recent studies of Student Learning. Assess. Eval. High Educ. 1985, 10, 225-235. [CrossRef]

44. Córdoba, M. Implantación de un Modelo Pluridisciplinar de Evaluación Formativa Continua Mediante la Realización y Análisis de Pruebas Objetivas Desde Nuevas Plataformas ON-LINE; Universidad Complutense de Madrid: Madrid, Spain, 2016.

45. Guimarães, D. "Kahoot: Quizzes Debates e Sondagens" in Apps Para Dispositivos Móveis: Manual Para Professores Formadores e Bibliotecários; Ministério da Educação, Direção-Geral da Educação: Lisboa, Portugal, 2015; pp. 203-224.

46. Rodríguez-Fernández, L. Smartphones y aprendizaje: El uso de Kahoot en el aula universitaria. Revista Mediterránea de Comunicación/Mediterr. J. Commun. 2017, 8, 181-189. [CrossRef]

47. Wang, A.I. The Wear out Effect of a Game-based Student Response System. Comput. Educ. 2015, 82, $217-227$. [CrossRef]

48. Sacristán San Cristobal, M.; Martín, R.; Navarro, E.; Tourón, J. Flipped Classroom y Didáctica de las Matemáticas en la Formación online de Maestros de Educación Infantil. Revista Electrónica Interuniversitaria de Formación de Profesorado 2017, 20, 1-14. [CrossRef]

49. Ramírez-Montoya, M.S.; García-Peñalvo, F.J. La integración efectiva del dispositivo móvil en la educación y en el aprendizaje. RIED Revista Iberoamericana de Educación a Distancia 2017, 20, 29-47. [CrossRef]

(C) 2019 by the authors. Licensee MDPI, Basel, Switzerland. This article is an open access article distributed under the terms and conditions of the Creative Commons Attribution (CC BY) license (http:/ / creativecommons.org/licenses/by/4.0/). 